\title{
Batrachochytrium dendrobatidis: requirement for further isolate collection and archiving
}

\author{
Jamie Voyles ${ }^{1, *}$, Katy Richards-Hrdlicka ${ }^{2}$, Scott D. Cashins ${ }^{1}$, Erica B. Rosenblum ${ }^{3}$, \\ Alex D. Hyatt ${ }^{4}$, Lee Berger ${ }^{1}$, Lee F. Skerratt ${ }^{1}$ \\ ${ }^{1}$ School of Public Health, Tropical Medicine and Rehabilitation Sciences, Amphibian Disease Ecology Group, \\ James Cook University, Townsville, Queensland 4811, Australia \\ ${ }^{2}$ School of Forestry and Environmental Sciences, Yale University, New Haven, Connecticut 06520, USA \\ ${ }^{3}$ Department of Biological Sciences, University of Idaho, Moscow, Idaho 83844, USA \\ ${ }^{4}$ Australian Animal Health Laboratory, CSIRO Livestock Industries, Geelong, Victoria 3220, Australia
}

\begin{abstract}
The fungal pathogen Batrachochytrium dendrobatidis $(B d)$ causes the disease chytridiomycosis, which is lethal to many species of amphibians worldwide. Many studies have investigated the epidemiology of chytridiomycosis in amphibian populations, but few have considered possible host-pathogen coevolution. More specifically, investigations focused on the evolution of $B d$, and the link with $B d$ virulence, are needed. Such studies, which may be important for conservation management of amphibians, depend on access to $B d$ isolates. Here we provide a summary of known $B d$ isolates that have been collected and archived in various locations around the world. Of $257 B d$ isolates, we found that $53 \%$ originate from ranids in the United States. In many cases, detailed information on isolate origin is unavailable, and it is unknown how many isolates are cryo-archived. We suggest the creation of a centralized database of isolate information, and we urge researchers and managers to isolate and archive $B d$ to facilitate future research on chytridiomycosis.
\end{abstract}

KEY WORDS: Amphibian declines $\cdot$ Batrachochytrium dendrobatidis $\cdot$ Chytridiomycosis $\cdot$ Pathogen preservation $\cdot$ Wildlife disease

Resale or republication not permitted without written consent of the publisher

\section{INTRODUCTION}

Chytridiomycosis is caused by the fungal pathogen Batrachochytrium dendrobatidis ( $B d$; Berger et al. 1998, Longcore et al. 1999). In infected amphibians, $B d$ is found in the superficial layers of the epidermis and disrupts normal osmoregulatory functioning in the skin (Berger et al. 1998, Voyles et al. 2007, 2009a). Mass mortality events have coincided with the appearance of $B d$ in wild amphibian populations (Berger et al. 1998, Lips et al. 2006). The effect on some host species is extreme, leading to dramatic declines and possibly extinctions (Schloegel et al. 2006, Skerratt et al. 2007). Some populations that survive initial declines persist with various levels of infection (Retallick et al. 2004, Woodhams \& Alford 2005), and Bd maintains at least moderate virulence in some species many years after introduction (Murray et al. 2009). These observations may be explained by factors such as variability in host resistance (Woodhams et al. 2007), host behavior (Rowley \& Alford 2007), or environmental characteristics (James et al. 2009), but shifts in $B d$ virulence are also plausible.

Some evidence supports the possibility of differential virulence among $B d$ isolates. Laboratory experiments suggest that $B d$ virulence differs among isolates when introduced to a single susceptible amphibian species (Berger et al. 2005, Retallick \& Miera 2007). In addition, phenotypic differences among isolates in proteomic signatures, morphological characteristics, and zoospore production (Fisher et al. 2009) could be associated with differences in virulence, although the mol- 
ecular basis for any differences in isolate virulence has not yet been identified. There seems to be relatively low genetic variability among isolates collected from globally widespread sources (Morehouse et al. 2003, James et al. 2009), but a recent study reported differential virulence among $B d$ strains that were either endemic to Japanese native amphibians or associated with introduced species (Goka et al. 2009). The possibility of differential virulence among distinct isolates highlights the requirement for ongoing surveillance, continued development of diagnostic assays for $B d_{\text {, }}$ and further virulence research. However, advances in chytridiomycosis research will require access to $B d$ isolates. The methods for isolating and purifying $B d$ were first established in 1999 (Longcore et al. 1999). Some $B d$ isolates have been cryo-archived for future research (Boyle et al. 2003), and many are actively passaged under different nutrient and temperature conditions. Here we review available information on known $B d$ isolates.

\section{MATERIALS AND METHODS}

Isolate records were gathered from personal lists (L. Berger, James Cook University; A. Hyatt, CSIRO Australian Animal Health Laboratories; J. Longcore, University of Maine) and peer-reviewed papers (Morehouse et al. 2003, Berger et al. 2005, Morgan et al. 2007, Rosenblum et al. 2008, Symonds et al. 2008, Fisher et al. 2009, James et al. 2009). The database is comprised of information for 257 isolates, which probably represent a subset of all existing isolates (i.e. information on additional isolates may not be currently available in the published literature). We collected as much information as possible on isolate origin (host species, life stage, location, and disease status), isolate storage history (passage history, location, current storage conditions), and contact information for researchers working with isolates.

\section{RESULTS}

The majority of $B d$ isolates, approximately $53 \%$, originate from ranids in the USA. However, a disproportionate number of originate from Rana muscosa (44 isolates) and $R$. sierrae (57 isolates) that were collected for a population genetics study in California (Morgan et al. 2007). Only 2 isolates come from caudates (Fig. 1). Most of the isolates (156) are from amphibian populations in the United States, which again is a reflection of the large number of isolates collected from $R$. muscosa and $R$. sierrae in California (Morgan et al. 2007).

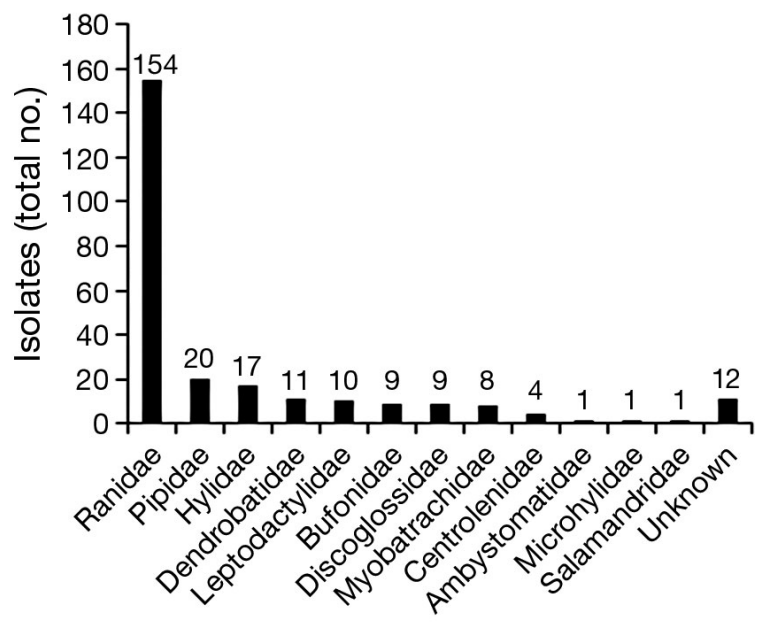

Fig. 1. Batrachochytrium dendrobatidis. Number of isolates per amphibian family collected and maintained in laboratory collections

Additional information on these isolates such as isolate origin (host species, date, life stage, location, disease status) and isolate storage history (passage history, location, current storage conditions) was collected whenever possible. Detailed information was difficult to obtain from the published literature, and in some cases no details were available. Of the identified isolates, little to no information was available about which isolates have been cryo-archived and are thus available for future research. Additionally, our analysis of available $B d$ isolates suggests that very few isolates are being collected and archived from important regions where $B d$-associated amphibian declines have occurred, or may be currently taking place (e.g. Central America: Republic of Panama, Woodhams et al. 2008; Montserrat, G. Garcia pers. comm.; Southeast Asia: Indonesia, Kusrini et al. 2008; Philippines, R. Brown pers. comm.).

\section{DISCUSSION}

Confronting disease-related declines requires addressing a specific set of problems: identifying the etiological agent and possible point of origin, developing diagnostic assays and sampling protocols, and understanding the mechanisms of pathogenesis, transmission, and evolution of host-pathogen dynamics. Many of these challenges have been successfully addressed (e.g. Berger et al. 1998, Boyle et al. 2003, Hyatt et al. 2007, James et al. 2009, Voyles et al. 2009a), but others are still being investigated. To facilitate projects that will meet these challenges, we recommend that additional $B d$ isolates be collected and cryo-archived. 
Table 1. Summary of Batrachochytrium dendrobatidis $(B d)$ isolates. Isolate records were collected from published literature and personal lists. Host species refers to the amphibian species from which $B d$ was originally isolated

\begin{tabular}{|c|c|c|c|}
\hline Host & Total & Host & Total \\
\hline Canada & 12 & Brazil & 1 \\
\hline Rana catesbeiana & 12 & Rana catesbeiana & 1 \\
\hline USA & 156 & Peru & 1 \\
\hline Ambystoma tigrinum & 1 & Unknown species & 1 \\
\hline Bufo americanus & 1 & Venezuela & 2 \\
\hline Bufo boreas & 4 & Rana catesbeiana & 2 \\
\hline Bufo haematiticus & 1 & South America (country unknown) & 3 \\
\hline Dendrobates auratus & 1 & Cochranella albomaculata & 1 \\
\hline Dendrobates azureus & 5 & Colostethus flotator & 1 \\
\hline Dyscophus guineti & 1 & Hyalinobatrachium colymbiphylum & 1 \\
\hline Hyla arenicolor & 1 & Puerto Rico & 1 \\
\hline Litoria caerulea & 1 & Eleutherodactylus coqui & 1 \\
\hline Rana aurora draytonii & 1 & Ghana & 3 \\
\hline Rana catesbeiana & 7 & Xenopus tropicalis & 3 \\
\hline Rana clamitans & 4 & South Africa & 7 \\
\hline Rana muscosa & 44 & Afrana fuscigula & 3 \\
\hline Rana palustris & 1 & Xenopus laevis & 4 \\
\hline Rana pipiens & 9 & Africa (country unknown) & 12 \\
\hline Rana sierrae & 57 & Xenopus laevis & 12 \\
\hline Rana sylvatica & 1 & Japan & 1 \\
\hline Rana yavapaiensis & 12 & Ceratophrys cranwelli & 1 \\
\hline Xenopus tropicalis & 1 & Australia & 15 \\
\hline Unknown species & 3 & Limnodynastes dumerilii & 1 \\
\hline Panama & 25 & Limnodynastes peronii & 1 \\
\hline Atelopus zeteki & 2 & Litoria booroolongensis & 1 \\
\hline Bufo haematiticus & 1 & Litoria caerulea & 2 \\
\hline Centrolenella ilex & 1 & Litoria lesueuri & 1 \\
\hline Cochranella euknemos & 1 & Litoria peronii & 1 \\
\hline Colostethus inguinalis & 3 & Litoria rheocola & 2 \\
\hline Colostethus nubicola & 1 & Mixophyes fasciolatus & 3 \\
\hline Eleutherodactylus bufoniformis & 1 & Mixophyes fleayi & 2 \\
\hline Eleutherodactylus caryophyllaceus & 2 & Nyctimystes dayi & 1 \\
\hline Eleutherodactylus museosus & 2 & Spain & 9 \\
\hline Eleutherodactylus podi-noblei & 1 & Alytes muletensis & 6 \\
\hline Eleutherodactylus talamancae & 2 & Alytes obstetricans & 3 \\
\hline Hyla pameri & 1 & UK & 1 \\
\hline Phyllomedusa lemur & 1 & Triturus vulgaris & 1 \\
\hline Smilisca phaeota & 4 & Unknown country & 8 \\
\hline \multirow[t]{2}{*}{ Smilisca sila } & 2 & Unknown species & 8 \\
\hline & & GRAND TOTAL & 257 \\
\hline
\end{tabular}

Priority targets for $B d$ collection and cryo-preservation have been suggested (Voyles et al. 2009b), and recording detailed information on any additional isolates will be important for basic disease research.

Although protocols for isolating (Longcore et al. 1999) and cryo-archiving (Boyle et al. 2003) Bd are readily available, some of the required skills are not standard for medical microbiology labs. Obtaining isolates can be difficult, requiring some technical skills and persistence. A tutorial on basic techniques is available in multiple languages (see www.bdbank.org) and can be used in conjunction with the published literature, regional training courses, and consultation with a World Organization for Animal Health (OIE) reference laboratory for chytridiomycosis (e.g. the Australian Animal Health Laboratory, Geelong). The Bdbank website provides an online forum to facilitate virulence research on $B d$. To that end, we hope to collate and standardize data on global isolates into a single database where information can be shared and accessed by chytridiomycosis researchers. Although isolate information can be cataloged on this website, there is, as yet, no formal arrangement for physical storage of isolates. Isolates can be archived at any laboratory, but for long-term storage and access, isolates should also be cryo-archived at the Australian Animal Health Laboratory, Geelong, Victoria.

Acknowledgements. We thank J. E. Longcore and D. Boyle for their contributions on isolate information. We also thank R. Brown, G. Garcia, J. Lopez, and Q. Bloxam for providing information on frog declines. 


\section{LITERATURE CITED}

Berger L, Speare R, Daszak P, Green DE and others (1998) Chytridiomycosis causes amphibian mortality associated with population declines in the rain forests of Australia and Central America. Proc Natl Acad Sci USA 95: 9031-9036

Berger L, Marantelli G, Skerratt LF, Speare R (2005) Virulence of the amphibian chytrid fungus Batrachochytium dendrobatidis varies with the strain. Dis Aquat Org 68: 47-50

Boyle DG, Hyatt AD, Daszak P, Berger L and others (2003) Cryo-archiving of Batrachochytrium dendrobatidis and other chytridiomycetes. Dis Aquat Org 56:59-64

Fisher MC, Bosch J, Yin Z, Stead DA and others (2009) Proteomic and phenotypic profiling of the amphibian pathogen Batrachochytrium dendrobatidis shows that genotype is linked to virulence. Mol Ecol 18:415-429

Goka K, Yokoyama J, Une Y, Kuroki T and others (2009) Amphibian chytridiomycosis in Japan: distribution, haplotypes, and possible route of entry into Japan. Mol Ecol 18: $4757-4774$

Hyatt AD, Boyle DG, Olsen V, Boyle DB and others (2007) Diagnostic assays and sampling protocols for the detection of Batrachochytrium dendrobatidis. Dis Aquat Org 73:175-192

James TY, Litvintseva AP, Vilgalys R, Morgan JAT and others (2009) Rapid global expansion of the fungal disease chytridiomycosis into declining and health amphibian populations. PLoS Pathog 5:e1000458, doi:10.1371/journal.ppat. 1000458

Kusrini MD, Skerratt LF, Garland S, Berger L, Endarwin W (2008) Chytridiomycosis in frogs of Mount Gede Pangrango, Indonesia. Dis Aquat Org 82:187-194

Lips KR, Brem F, Brenes R, Reeve JD and others (2006) Emerging infectious disease and the loss of biodiversity in a Neotropical amphibian community. Proc Natl Acad Sci USA 103:3165-3170

Longcore JE, Pessier AP, Nichols DK (1999) Batrachochytrium dendrobatidis gen. et sp. nov., a chytrid pathogenic to amphibians. Mycologia 91:219-227

> Morehouse EA, James TY, Ganley ARD, Vilgalys R, Berger L, Murphy PJ, Longcore JE (2003) Multilocus sequence typing suggests the chytrid pathogen of amphibians is a recently emerged clone. Mol Ecol 12:395-403

Morgan JAT, Vredenburg VT, Rachowicz LJ, Knapp RA and others (2007) Population genetics of the frog-killing fungus Batrachochytrium dendrobatidis. Proc Natl Acad Sci USA 104:13845-13850

Murray KA, Skerratt LF, Speare R, McCallum H (2009) Impact

Editorial responsibility: Cynthia Carey,

Boulder, Colorado, USA and dynamics of disease in species threatened by the amphibian chytrid fungus, Batrachochytrium dendrobatidis. Conserv Biol 23:1242-1252

Retallick RWR, Miera V (2007) Strain differences in the amphibian chytrid Batrachochytrium dendrobatidis and non-permanent, sub-lethal effects of infection. Dis Aquat Org 75:201-207

Retallick RWR, McCallum H, Speare R (2004) Endemic infection of the amphibian chytrid fungus in a frog community post-decline. PLoS Biol 2:e351, doi:10.1371/journal. pbio.0020351

Rosenblum EB, Stajich JE, Maddox N, Eisen MB (2008) Global gene expression profiles for life stages of the deadly amphibian pathogen Batrachochytrium dendrobatidis. Proc Natl Acad Sci USA 105:17034-17039

> Rowley JJL, Alford RA (2007) Behaviour of Australian rainforest stream frogs may affect the transmission of chytridiomycosis. Dis Aquat Org 77:1-9

Schloegel LM, Hero JM, Berger L, Speare R, McDonald K, Daszak P (2006) The decline of the sharp-snouted day frog (Taudactylus acutirostris): the first documented case of extinction by infection in a free-ranging wildlife species? EcoHealth 3:35-40

Skerratt LF, Berger L, Speare R, Cashins S and others (2007) Spread of chytridiomycosis has caused the rapid global decline and extinction of frogs. EcoHealth 4:125-134

Symonds EP, Trott DJ, Bird PS, Mills P (2008) Growth characteristics and enzyme activity in Batrachochytrium dendrobatidis isolates. Mycopathologia 166:143-147

> Voyles J, Berger L, Young S, Speare R and others (2007) Electrolyte depletion and osmotic imbalance in amphibians with chytridiomycosis. Dis Aquat Org 77:113-118

Voyles J, Young S, Berger L, Campbell C and others (2009a) Pathogenesis of chytridiomycosis, a cause of catastrophic amphibian declines. Science 326:582-585

Voyles J, Cashins SD, Rosenblum EB, Puschendorf R (2009b) Preserving pathogens for wildlife conservation: a case for action on amphibian declines. Oryx 43:527-529

- Woodhams DC, Alford RA (2005) Ecology of chytridiomycosis in rainforest stream frog assemblages of tropical Queensland. Conserv Biol 19:1449-1459

Woodhams DC, Rollins-Smith LA, Alford RA, Simon MA, Harris RN (2007) Innate immune defenses of amphibian skin: antimicrobial peptides and more. Anim Conserv 10: $425-428$

Woodhams DC, Kilburn VL, Reinert LK, Voyles J and others (2008) Chytridiomycosis and amphibian population declines continue to spread eastward in Panama. EcoHealth 5:268-274

Submitted: September 2, 2009; Accepted: February 10, 2010 Proofs received from author(s): April 23, 2010 